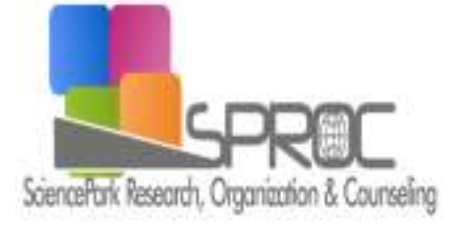

K

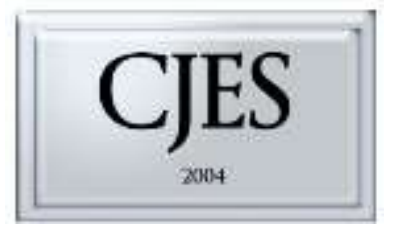

http://sproc.org/ojs/index.php/cjes/

\title{
Validity and reliability dissertation of the scale used for determination of perceptions and attitudes of teacher's proficiency in tablet pc-supported education
}

Vasfi Tugun *

Suggested Citation:

Educational Science. 11

Cypriot Journal of

K

Abstract

L 
1. Introduction

\section{Aim of The Research}

3. Method

3.1. Study Group 


\subsection{Development of The Scale}

L

3.3. Application

4. Results 
Cypriot Journal of Educational Science. 11

\subsection{Validity}


Factor II: Teachers' attitudes towards tablet-supported education $\alpha=.934$

4.2. Reliability 


\section{Discussion}

\section{Conclusion}

\section{Acknowledgements}

\section{References}

Electronic Turkish Studies, 8

\section{Cypriot Journal of Educational Sciences, 5}

Turkish Online Journal of Educational Technology, 3(2),

Sosyal bilimler icin veri analizi el kitabi.

John Wiley\&SonsInc., 1, 
Procedia Social and Behavioral Sciences, 2,

K

Learning Environments Research, 7

$\mathrm{L}$

SDU International Journal of Educational Studies, 1(1),

$\mathrm{K}$

Computer, 40(9),

L

John Wiley Sonc Inc, New York, 116

L

Degisen dunyada teknoloji yonetimi, bilisim teknolojiler

International Journal of Science Education, 27(13),

L

International Journal of Science Education,

22(4),

World Journal on Educational Technology, 7(2), 